\title{
TOXICITY OF NEEM AND PYRETHRUM EXTRACTS TO ADULT GRASS GRUB
}

\author{
M.S. QURESHI, T.A. JACKSON, R.J. TOWNSEND and D.J. SAVILLE \\ Biocontrol and Biosecurity, AgResearch, PO Box 60, Lincoln \\ Corresponding author: sohail.qureshi@agresearch.co.nz
}

\begin{abstract}
Grass grub, Costelytra zealandica, larvae damage pastures and crops by root feeding while the adult beetles can be serious defoliators of a wide range of plants. Control of this pest with botanical insecticides has received little attention. The objectives of this study were to investigate the direct effects of neem and pyrethrum extracts on the adult beetle. A laboratory bioassay was used to test the acute and chronic effects of the botanicals over a range of doses by treating a food source (Pittosporum tenuifolium) with the extracts. Pyrethrum had the faster action; at all doses beetles were killed within a day. Neem caused only low mortality even at the highest rate. Similar results were obtained when the bioassays were repeated using the same treatments for Smith's chafer (Odontria smithii) beetle. Further research is needed on the practical implications of these results.

Keywords: Costelytra zealandica, Odontria smithii, neem, pyrethrum, garlic extract.
\end{abstract}

\section{INTRODUCTION}

Adult grass grubs, Costelytra zealandica (White), are a serious pest of a number of horticultural crops in New Zealand, e.g. kiwifruit (Blank \& Olson 1984), tamarillo (Blank et al. 1983), blueberries (East \& Holland 1984) and orchard crops (East et al. 1983).

Application of insecticides against the adult stage of the grass grub life cycle has theoretical advantages over the procedure of applying insecticides against the pasture damaging larval stages. An additional mortality at the adult stage will add to the mortalities operating earlier in the life cycle, increasing the chances that total generation mortality will exceed the constant mortality rate (Pottinger 1967) and thus cause a population decline in the next generation.

Compared with research into larval control, little effort has been put into attempts to control grass grub as adults, despite the advantages this would offer. Insecticidal treatments of adult grass grub as a possible alternative to larval control has been investigated by Fenemore and co-workers $(1963 ; 1968 ; 1970)$. Their screening of a range of materials did not reveal any that were particularly effective as soil or foliar treatments. Henzell \& Lauren (1978) demonstrated the need for high contact activity and rapid action for foliar treatments. Although synthetic pyrethroids fulfil these requirements, other materials may also be suitable.

In the past, the impact of grass grub has been minimised by the use of management methods (Kelsey 1951) and synthetic insecticides (Trought 1979). Recently, insect resistance, pest resurgence, chemical residues and high cost have all acted to reduce the use of chemical insecticides which now have only limited use against this pest. Two widely proven organic insecticidal plant-extracts are those from pyrethrum (Chrysanthemum cinerariaefolium Trevir. Vis) and neem (Azadirachta indica A. Juss), but little is known about their action against scarabaeids. In this paper we investigate the activity of these two plant extracts against adult grass grubs, and also against Odontria beetles which have been recorded damaging trees in an organic olive orchard (Townsend et al. 2001).

New Zealand Plant Protection 55:298-302 (2002) 


\section{MATERIALS AND METHODS}

Grass grub beetles were obtained on 13 November 2001 from a mown grass sward at Lincoln. In the laboratory on 19 November, plastic tubes $(3 \mathrm{~cm}$ diameter $x 13 \mathrm{~cm}$ deep) were filled to a depth of $7 \mathrm{~cm}$ with moist soil (ca 20\% soil moisture), and a grass grub beetle was placed on the soil surface in each tube. Beetles were prescreened for vigour by discarding those that had not burrowed into the soil within $5 \mathrm{~min}$ under lamplight. A treated leaf (Pittosporum tenuifolium Sol.) $(1.8 \mathrm{~cm}$ diameter) was then placed on the soil surface of each tube before closing with a vented lid.

Experimental treatments were three rates of each of two organic insecticides (NeemAzal (active ingredient $10 \mathrm{~g} /$ litre azadirachtin) or 'Garlic and pyrethrum' (active ingredient $12 \mathrm{~g} /$ litre pyrethrum)), plus the recommended rate of a standard (Fastac) synthetic insecticide $(0.5 \mathrm{ml}$ of product /litre water). Fastac contains $10 \%$ of alphacypermethrin as the active ingredient. For each organic insecticide, the rates used were the rate recommended for aphids, thrips, leaf hoppers and caterpillars (Garlic and pyrethrum; $25 \mathrm{ml} /$ litre water) or for aphids, thrips, whitefly, leaf miners, scale insects and mealy bug (NeemAzal; $5 \mathrm{ml} /$ litre water), and 3-fold above and below the recommended rate. Three "water only" controls were also included.

Three tubes constituted a "plot" in the randomised block experimental design. There were ten plots consisting of three control plots and seven treated plots per block, with four replicate blocks. Leaves were treated in this random order by dipping for 1-2 seconds into one of the eight solutions ( 7 insecticides plus water), and then placing them in the tubes.

The leaves were checked for signs of feeding and beetle death after three $24 \mathrm{~h}$ periods. Feeding was defined as any visible sign of chewing, with the percentage of the leaf removed being recorded as the percent eaten by the beetle. At each assessment time, feeding on leaves was recorded for each tube, then all leaves were discarded and beetles replaced on the soil surface within their tubes. After a further $5 \mathrm{~min}$ beetles remaining on the surface under a $100 \mathrm{~W}$ lamp (placed $30 \mathrm{~cm}$ above) were scored as dead. This method of determining death (including moribund) is similar to that used by Henzell \& Lauren (1978). Freshly prepared treated leaves were then placed in the tubes so that each beetle received a leaf similar to that which it had previously been offered.

The above bioassay was repeated on 19 February, 2002 with exactly the same treatments against Odontria beetles collected on 12 February from a residential property in Halswell, near Christchurch.

Mortality and feeding data from each of the two bioassays were subjected to analysis of variance for each assessment. A linear contrast in the three rates of NeemAzal was examined, with rates treated as evenly spaced. Treatments with constant values $(0$ or $100 \%$ ) were omitted, with comparisons involving these treatments being carried out using chi-squared tests.

\section{Grass grub beetles}

\section{RESULTS}

Grass grub beetles given leaves treated with 'Garlic and Pyrethrum' did not eat any leaf and were all dead within $24 \mathrm{~h}$ except for one beetle at the highest rate (Table 1). Beetles given leaves treated with Fastac did not eat any of the leaves and were all dead within 72 hours. Beetles given leaves treated with NeemAzal continued eating for the duration of the trial $(72 \mathrm{~h})$, although they ate significantly less than the control beetles during the first $24 \mathrm{~h}(\mathrm{P}<0.01)$, with the difference being non-significant at 48 and $72 \mathrm{~h}$ except at the highest rate of NeemAzal. By $72 \mathrm{~h}$ beetles given leaves treated with NeemAzal had suffered significant mortality $(\mathrm{P}<0.01)$ compared to the control beetles. There was no significant trend with increasing rate of NeemAzal for any of the six variables. 
TABLE 1: Mean percentage survival and percentage of leaf eaten after 24, 48 and $72 \mathrm{~h}$ for each treatment for grass grub beetles. Treatments with means in brackets have been omitted from the analysis. The first LSD is for comparisons with the control, whereas the second is for all other comparisons.

\begin{tabular}{lcccccccc}
\hline & \multicolumn{3}{c}{ Survival (\%) } & & \multicolumn{3}{c}{ Leaf eaten (\%) } \\
\cline { 2 - 3 } Treatments & $24 \mathrm{~h}$ & $48 \mathrm{~h}$ & $72 \mathrm{~h}$ & & $24 \mathrm{~h}$ & $48 \mathrm{~h}$ & $72 \mathrm{~h}$ \\
\hline Garlic \& Pyre, rec. rate /3 & $(0)$ & $(0)$ & $(0)$ & & $(0.0)$ & $(0.0)$ & $(0.0)$ \\
Garlic \& Pyre, rec. rate & $(0)$ & $(0)$ & $(0)$ & & $(0.0)$ & $(0.0)$ & $(0.0)$ \\
Garlic \& Pyre, rec. rate x3 & $(8)$ & $(0)$ & $(0)$ & & $(0.0)$ & $(0.0)$ & $(0.0)$ \\
NeemAzal, rec. rate /3 & 92 & 67 & 67 & & 0.8 & 2.9 & 1.2 \\
NeemAzal, rec. rate & 83 & 83 & 75 & & 2.9 & 5.0 & 8.3 \\
NeemAzal, rec. rate x3 & 75 & 67 & 58 & & 3.3 & 0.4 & 0.4 \\
Fastac, rec. rate & 75 & 33 & $(0)$ & & $(0.0)$ & $(0.0)$ & $(0.0)$ \\
Control & 97 & 97 & 94 & & 24.9 & 11.9 & 14.4 \\
LSD(5\%)[Ctrl vs Trtd] & 26 & 23 & 27 & & 10.8 & 9.4 & 13.4 \\
LSD(5\%)[Trtd vs Trtd] & 32 & 28 & 33 & & 13.2 & 11.5 & 16.5 \\
\hline
\end{tabular}

Odontria beetles

Results with Odontria beetles (Table 2) were similar to those with grass grub beetles with a few exceptions. Odontria beetles ate none of the leaves treated with either 'Garlic and Pyrethrum' or Fastac. Beetles given leaves treated with 'Garlic and Pyrethrum' at the recommended or 3-times-recommended rates were all dead within $24 \mathrm{~h}$, while at the lowest rate, survival was $67 \%$ after $24 \mathrm{~h}$, reducing to $8 \%$ after $72 \mathrm{~h}$ (Table 2). Beetles given leaves treated with Fastac were all dead within $24 \mathrm{~h}$ with the exception of one beetle which was dead after $48 \mathrm{~h}$. Beetles given leaves treated with NeemAzal continued feeding up until $72 \mathrm{~h}$ except at the highest rate where beetles ate no leaf beyond $48 \mathrm{~h}$. During the first $24 \mathrm{~h}$ the beetles with the recommended and 3-times-recommended rates of NeemAzal

TABLE 2: Mean percentage survival and percentage of leaf eaten after 24, 48 and $72 \mathrm{~h}$ for each treatment for Odontria beetles. Treatments with means in brackets have been omitted from the analysis. The first LSD is for comparisons with the control, whereas the second is for all other comparisons.

\begin{tabular}{lccccccc}
\hline & \multicolumn{3}{c}{ Percentage Survival } & & \multicolumn{3}{c}{ Percentage Leaf Eaten } \\
\cline { 2 - 3 } Treatments & $24 \mathrm{~h}$ & $48 \mathrm{~h}$ & $72 \mathrm{~h}$ & & $24 \mathrm{~h}$ & $48 \mathrm{~h}$ & $72 \mathrm{~h}$ \\
\hline Garlic \& Pyre, rec. rate /3 & $(67)$ & $(17)$ & $(8)$ & & $(0.0)$ & $(0.0)$ & $(0.0)$ \\
Garlic \& Pyre, rec. rate & $(0)$ & $(0)$ & $(0)$ & & $(0.0)$ & $(0.0)$ & $(0.0)$ \\
Garlic \& Pyre, rec. rate x3 & $(0)$ & $(0)$ & $(0)$ & & $(0.0)$ & $(0.0)$ & $(0.0)$ \\
NeemAzal, rec. rate /3 & $(100)$ & 92 & 92 & & 4.6 & 1.3 & 3.3 \\
NeemAzal, rec. rate & $(100)$ & 92 & 50 & & 25.0 & 8.8 & 4.6 \\
NeemAzal, rec. rate x3 & $(100)$ & 75 & 42 & & 20.4 & 13.3 & 0.0 \\
Fastac, rec. rate & $(8)$ & $(0)$ & $(0)$ & & $(0.0)$ & $(0.0)$ & $(0.0)$ \\
Control & $(100)$ & $(100)$ & $(100)$ & & 10.3 & 15.3 & 8.5 \\
LSD(5\%)[Ctrl vs Trtd] & - & - & - & & 15.8 & 14.1 & 8.8 \\
LSD(5\%)[Trtd vs Trtd] & - & 33 & 52 & & 19.4 & 17.3 & 10.8 \\
\hline
\end{tabular}


tended to eat more than the control beetles $(\mathrm{P}<0.10)$. There was no mortality in the NeemAzal treatments during the first $24 \mathrm{~h}$, with $50 \%$ and $58 \%$ mortality at the recommended or 3-times-recommended rates respectively after $72 \mathrm{~h}$. The latter mortality rates were significantly higher than that of the control beetles using a chisquared test $(\mathrm{P}<0.01)$. There was no significant linear trend with increasing rate of NeemAzal for any of the six variables, with the exception of a possible trend of increasing mortality after 72 hours $(\mathrm{P}<0.10)$.

\section{DISCUSSION}

For both species of beetle, 'Garlic and Pyrethrum' had rapid knockdown effect. At the low rate of 'Garlic and Pyrethrum' Odontria beetles appeared to survive better than grass grub beetles, perhaps because of their larger size. Fastac had more rapid knockdown effect against Odontria beetles than grass grub beetles (in spite of their larger size); although at $72 \mathrm{~h}$ the mortality was $100 \%$ for both types of beetle. When Fastac, the standard synthetic insecticide treatment, and 'Garlic and Pyrethrum' (organic) were compared at their recommended rates, the two products had similarly high knockdown effect after $24 \mathrm{~h}$ for Odontria beetles, while for grass grub beetles, Fastac was slower acting than 'Garlic and Pyrethrum'. In the case of both 'Garlic and Pyrethrum' and Fastac, no leaf was consumed by any of the beetles, so ingestion was presumably not the cause of death.

NeemAzal had poor knockdown effect for both types of beetle, even at the high rate and after $72 \mathrm{~h}$. In contrast to the other two treatments NeemAzal-treated leaf was consumed by both species of beetle. NeemAzal is a slow-acting insect growth regulator normally used against immature stages of the insects. There have been no claims of efficacy against adult beetles in New Zealand and these experiments have confirmed that this product is not promising for rapid knockdown. A possible use for the product could be to reduce fecundity (Anon 1992) by spraying at dusk when beetles are in flight, thereby allowing more of the insecticide to come into contact with the body of the beetle, although no work has yet been carried out on this topic.

The modes of action of 'Garlic and Pyrethrum' are given as contact (pyrethrum) and repellency (garlic oil; at $14 \mathrm{ml} /$ litre of product) (New Zealand Agrichemical Manual 2001). The high knockdown effect at one-third of the recommended rate in these trials was greater than we expected from the action of pyrethrum alone and, when queried, the manufacturer informed us that the oils component has a fumigant effect in confined spaces, such as the tubes used in our experiments (T. Robinson, Betta-Crop Organics Limited, pers. comm.). Therefore the results of our experiments are not directly applicable to field conditions.

As the trials were conducted in the laboratory under fluorescent light and in a $15^{\circ} \mathrm{C}$ Contherm incubator there was minimal UV light challenge to the plant extract components of these treatment. Further work is needed to explore the fumigant effect of the 'Garlic and Pyrethrum' treatment and to investigate the effects of UV light on both of the organic treatments under field conditions.

\section{ACKNOWLEDGEMENTS}

We thank Peter de Jong, Yates New Zealand Limited, for helpful discussions.

\section{REFERENCES}

Anon. 1992: Important features of insecticides currently used or under development for the protection of stored grain. FAO Plant Production and Protection Paper No. 42. FAO, Rome.

Blank, R.H.; Olson, M.H. 1984: Insecticide protection of kiwifruit vines from attack by grass grub beetle. Proc. 37th N.Z. Weed and Pest Control Conf:: 130-135. 
Blank, R.H.; Olson, M.H.; Bell, D.S. 1983: Screening insecticides to protect tamarillo against grass grub adults. Proc. 36th N.Z. Weed and Pest Control Conf: 111-115.

East, R.; Holland, P.T. 1984: Control of grass grub beetles in blueberries. Proc. 37th N.Z. Weed and Pest Control Conf.: 228-230.

East, R.; Willoughby, B.E.; Koller, M.S. 1983: Defoliation by grass grub beetles in Waikato orchards. Proc. 36th N.Z. Weed and Pest Control Conf:: 151-155.

Fenemore, P.G. 1963: Prospects for alternative chemical methods of grass grub control. Proc. 17th N.Z. Weed and Pest Control Conf.: 135-140.

Fenemore, P.G. 1968: The requirements of an insecticide treatment for control of grass grub adults. Proc. 21st N.Z. Weed and Pest Control Conf: : 221-224.

Fenemore, P.G.; Perrott, D.C.F. 1970: Possible control of the melolonthid Costelytra zealandica (White) using transient insecticides against the adult. N.Z. JAgric. Res. 13: 69-86.

Henzell, R.F.; Lauren, D.R. 1978: Contact activity of synthetic pyrethroids against adult grass grub. Costelytra zealandica (White). Pesticide Sci. 9: 582-586.

Kelsey, J.M. 1951: Grass grub and grass caterpillar control. N.Z. J. Agric. 83: 113-122.

New Zealand Agrichemical Manual 2001: WHAM Chemsafe Limited, Wellington.

Pottinger, R.P. 1967: An ecological approach to the study of insects. N.Z. Agric. Sci. 1(12): 8-12.

Townsend, R.J.; Hurni, S.; Jackson, T.J. 2001: Odontria smithii defoliates olives in the Waihopai Valley. N.Z. Plant Prot. 54: 256.

Trought, T.E.T. (1979). Review of chemical control of Costelytra zealandica in New Zealand, 1968-1978 (Coleoptera: Scarabaeidae). Proc. 2nd Australasian Conf. Grassland Invert. Ecol.: 160-165. 